\title{
Point Load Index of Rocks Exposed to High Thermal Effect
}

\author{
M. Sobhey ${ }^{1}$, M. Shahien2, M. El Sawwaf ${ }^{3}$ and A. Farouk ${ }^{4}$ \\ ${ }^{1}$ Assistance Lecturer in Structural Engineering Department, Tanta University, Tanta, Egypt \\ E-mail: m.sobhey@f-eng.tanta.edu.eg \\ ${ }^{3}$ Professor in Structural Engineering Department, Tanta University, Tanta, Egypt \\ E-mail: marawan.shahin@f-eng.tanta.edu.eg \\ ${ }^{2}$ Professor in Structural Engineering Department, Tanta University, Tanta, Egypt \\ E-mail:mos_sawaf@hotmail.com \\ ${ }^{4}$ Associate Professor in Structural Engineering Department, Tanta University, Tanta, Egypt \\ E-mail: drafarouk@f-eng.tanta.edu.eg
}

\begin{abstract}
High thermal effects on Point Load Index (P.L.I) of rocks tolerate in mind an essential issue for numerous geotechnical engineering purposes. Many engineering relevancies interact with it as Geothermal power reserve extraction, Fires would occur in tunnels, Underground Coal Gasification (UCG), and numerous ancient monuments that were made from these rocks and exposed to different thermal impacts. This research aims to carry out (P.L.I) experimental studies of intact rocks as Granite, Sandstone, Marble and, Limestone rocks. In this study, the rock samples are subjected to thermal effects (from room temperature degree $25^{\circ} \mathrm{C}$ to a high temperature up to $1100{ }^{\circ} \mathrm{C}$ ). The results are debated and introduced in terms of rising temperature degrees with different parameters. It has been known that the (P.L.I) of rocks decreased with the elevated temperature, particularly outside certain temperatures.
\end{abstract}

Keywords: Rock Strength, Thermal Effects, Point Load Index, Different Rocks

\section{INTRODUCTION}

The impact of thermal effect on rocks is a topic of growing importance in geotechnical engineering. This topic is relevance to several engineering applications such as hot dry rock (HDR), deep geological disposal of nuclear waste, (Granitic rocks such as granite and diorite are widely acceptable site for nuclear waste disposal and are also main rock types of HDR reservoir) (at temperatures which generally vary from 100 to $300 \mathrm{oC}$ and will rise over the storage interval), geothermal energy resource extraction, solar heating of rock monuments and buildings, Fires in tunnels, mines and buildings and underground coal gasification (UCG). The process of Underground Coal Gasification (UCG) is based on in situ, sub-stoichiometric coal combustion for the production of a high-calorific synthesis gas, which can be applied for electricity generation. However, UCG can induce impacts such as high thermal effects on the surrounding rocks of the coal layer. Temperatures above $1,000{ }^{\circ} \mathrm{C}$ can be achieved in the UCG reactor and its close vicinity. The impact of high temperature on the physical and mechanical properties of rocks has been largely investigated using laboratory studies since the 1970s over the last several decades.

Numerous experiments in literature have shown that the temperature has a significant change in the rock strength parameters. Ferrero et al., 2001 tested 15 samples of two types of marble which were previously heated to temperatures up to $600{ }^{\circ} \mathrm{C}$ and later cooled. Koca et al. 2012 studied 9 samples of intact marble, under different temperatures observing the rock strength. These authors also tested five rock samples obtained from building elements previously exposed to fire (subjected to an estimated temperature of $500{ }^{\circ} \mathrm{C}$ ). Ranjith et al., 2012 tested sandstones until $1000{ }^{\circ} \mathrm{C}$ obtaining different results than in other works, reaching $180 \%$ of the initial strength at $600{ }^{\circ} \mathrm{C}$, then lowering until the maximum test temperature is reached. Xu et al., 2009 found that the granite UCS changes slightly from room temperature to $400{ }^{\circ} \mathrm{C}$, but dramatically decreases with temperature from $400{ }^{\circ} \mathrm{C}$ upward. Shao et al., 2015 studied the fracturing behavior of Australian granite test specimens such as the crack propagation at high temperatures up to $800{ }^{\circ} \mathrm{C}$ using electron microscopy scanning (SEM) and unconfined strength test. The results reveal that the failure modes of granite specimens changed from brittle fracturing to ductile failure with increasing temperature.

\section{Rock Samples (Granite, Sandstone, Limestone, and Marble)}

In this research, granite material was collected from a quarry at Shellal village (central quarry) in Aswan city. It was the traditional northern frontier of the Nubian region during the period of both Egyptian and Roman Empire. During the period of ancient Egypt, it was a very important quarry area for granite production. Some of the monuments known to come from this site are The unfinished obelisk, The Cleopatra's Needle, The sarcophagus at the burial chambers of the Third Dynasty Pharaoh Djoser at Saqqara, Aswan granite is pink in color and medium-grained.

While Sandstone material was collected from a quarry at Madinaty city (It is located in a site between Cairo and Suez highway road). There are several monuments known made from sandstone rocks are Statues of an Egyptian pharaoh, a Wall with pharaonic painting, and a Pharaonic mural in the Egyptian museum at Cairo. Sandstone rock color is yellow and medium to coarse-grained.

Limestone rocks were collected from a quarry in the western north of Madinaty city (It is located in a site between Cairo and Suez highway road), eastern desert. There are several monuments known made from Limestone rocks are Egyptian pharaoh Lion head and the Nefertiti Head in the Egyptian museum at Cairo. Limestone rock color is white to yellow. 
There are many quarries of different types of Marble rocks in Egypt. The sample was collected from a marble quarry in East of Asyout city. Many monuments known to come from this site are Pharaonic utensils in The Egyptian museum and many Statues of Egyptian pharaohs. The marble is white to yellow. It forms from limestone, which is subjected to the heat and pressure of metamorphism.

Drilled out of the adjacent part of a large block without any macroscopic cracks, the rock cores were prepared in cylinders with a diameter of $43 \mathrm{~mm}$ and a height of $50 \mathrm{~mm}$ for both Granite and Marble rocks, while with a diameter of $48 \mathrm{~mm}$ and a height of $50 \mathrm{~mm}$ for both sandstone and limestone rocks. To improve the accuracy of the experiments, each end faces of the rock samples were polished with an error of unevenness of less than $0.05 \mathrm{~mm}$. The average dry density is $27.7 \mathrm{kN} / \mathrm{m} 3$ for granite rocks, $24.4 \mathrm{kN} / \mathrm{m} 3$ for Sandstone rocks, $21.0 \mathrm{kN} / \mathrm{m} 3$ for Limestone rocks, and $27.2 \mathrm{kN} / \mathrm{m} 3$ for Marble rocks. Fig. 1 shows the location of the different collected rocks.

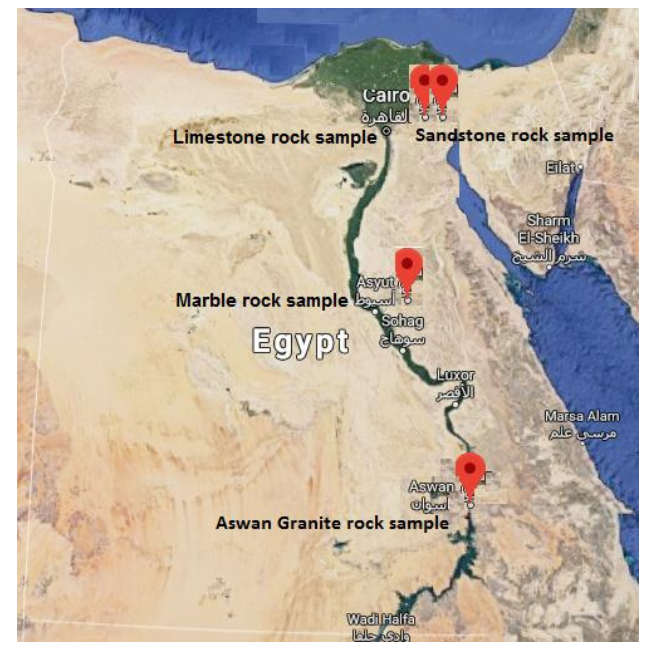

Figure 1. Location of the Granite, Sandstone, Limestone, and Marble rock quarries

\section{MATERIALS PREPARATION}

To eliminate the influences of natural water content on the experimental results, all the samples (Granite, Sandstone, Limestone, and Marble rocks) were first numbered and subjected to dry processing by putting the samples into a drying oven and baking them at $105{ }^{\circ} \mathrm{C}$ for $48 \mathrm{~h}$ to remove all moisture content as shown in Figures 2,3,4 and 5, respectively. Then, samples were placed in an electric hightemperature furnace. The designated high temperatures were $300{ }^{\circ} \mathrm{C}, 600{ }^{\circ} \mathrm{C}, 900{ }^{\circ} \mathrm{C}$ and $1100{ }^{\circ} \mathrm{C}$ respectively. In each case, the samples were heated at a certain rate $\left(5^{\circ} \mathrm{C} / \mathrm{min}\right)$ at atmospheric pressure to prevent occurring heat shock in the rock samples in a furnace until a certain temperature is reached and kept within the desired high temperature for different interval times 3,6,12 and 24 hours. Subsequently, the furnace was turned off and varieties of point load tests were conducted on rock samples either under hightemperature treatment (after heated) or after the samples were naturally cooled to room temperature (after cooling) as summarized in Table 1.

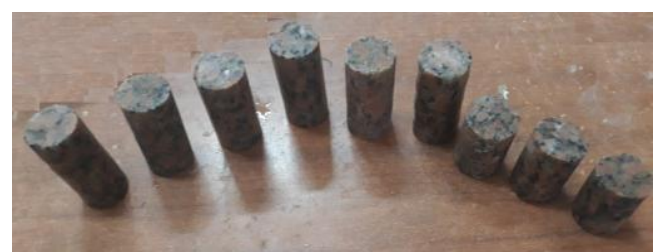

Figure 2. Shape of the Cylindrical Samples of Aswan Granite rocks

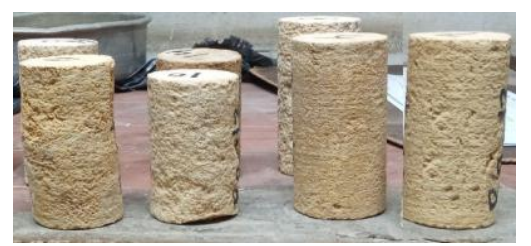

Figure 3. Shape of the Cylindrical Samples of Sandstone rocks

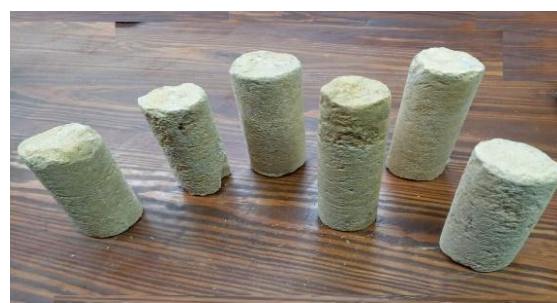

Figure 4. Shape of the Cylindrical Samples of Limestone rocks

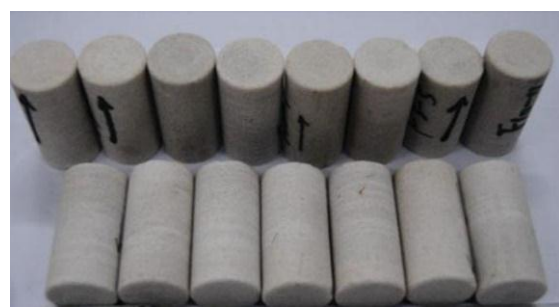

Figure 5. Shape of the Cylindrical Samples of Marble rocks

Table 1. Studied Cases of Thermal Effects

\begin{tabular}{|c|c|c|}
\hline $\begin{array}{c}\text { Cases of } \\
\text { Thermal } \\
\text { effects No. }\end{array}$ & $\begin{array}{c}\text { Period of Temperature } \\
\text { exposure (Hours) }\end{array}$ & $\begin{array}{c}\text { Period of cooling before } \\
\text { testing (Hours) }\end{array}$ \\
\hline 1 & 3 & 0 \\
\hline 2 & 3 & 24 \\
\hline 3 & 6 & 24 \\
\hline 4 & 12 & 24 \\
\hline 5 & 24 & 24 \\
\hline
\end{tabular}

\section{EXPERIMENTAL EQUIPMENT}

The treated samples were conserved in a desiccator Pointload index test. The maximum loading capacity of the uniaxial compression testing system is $1000 \mathrm{kN}$. The point load test procedure helps to determine the diametrical point load strength index for the core specimen. The sample is placed between two specific cones and the load is applied until its failure as shown in Fig. 6. The point load strength index can be estimated using the following equation:

Where,

$$
(\mathrm{PLI})=\mathrm{P} / \mathrm{D}^{2}(\mathrm{MPa})
$$

$\mathrm{D}=$ Equivalent core diameter in $\mathrm{mm}$

$\mathrm{P}=$ the breaking failure load in $\mathrm{N}$ 


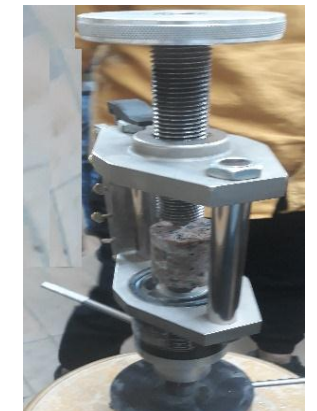

Figure 6. Point Load Test System

\section{RESULTS AND DISCUSSION OF THE EXPERIMENTAL WORK}

Figures 7, 8, 9, and 10 show the variation of (PLI) (MPa) with different heating for Granite, Sandstone, Limestone, and Marble rocks respectively for different and for heating periods, 3,6,12 and 24 hours after the samples were naturally cooled to room temperature (after cooling). While, in the case of heating period $3 \mathrm{hr}$., the variation of (PLI) (MPa) was conducted on rock samples both under high-temperature treatment (after heated) and after the samples were naturally cooled to room temperature (after cooling). Figure 11,12,13 and 14 show the mode of failure under the influence of heat after the PLI test for Granite, Sandstone, Limestone, and Marble rocks

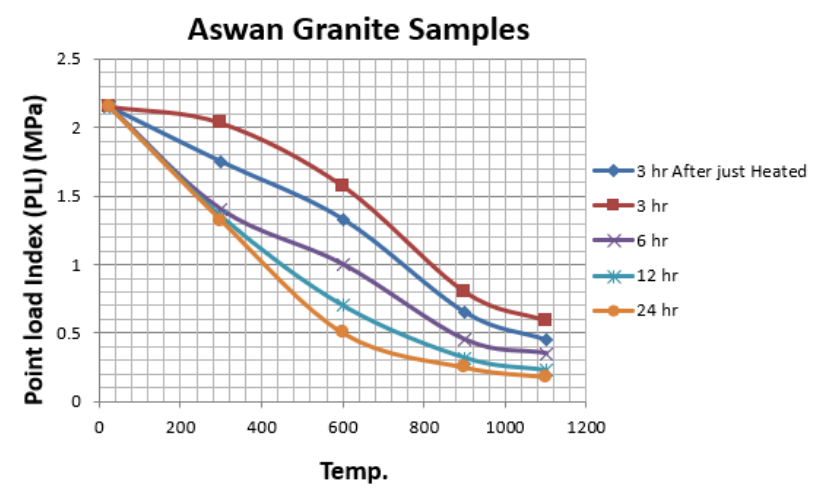

Figure 7 Variation of the (PLI) (MPa) of Aswan granite rock for different temperature degrees and heating periods

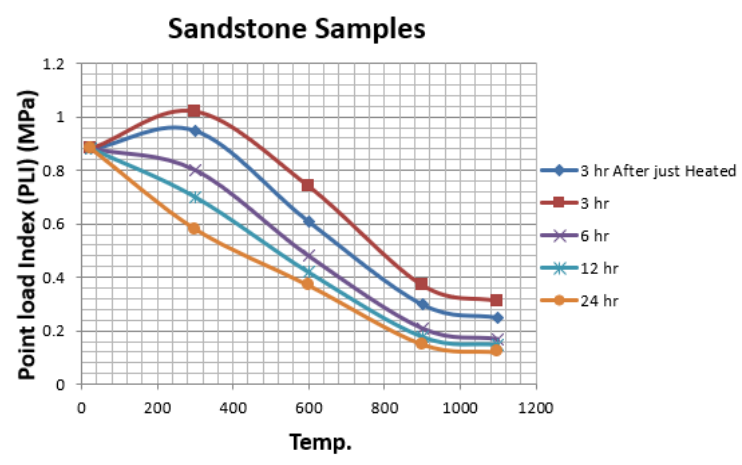

Figure 8 Variation of the (PLI) (MPa) of Sandstone rock for different temperature degrees and heating periods

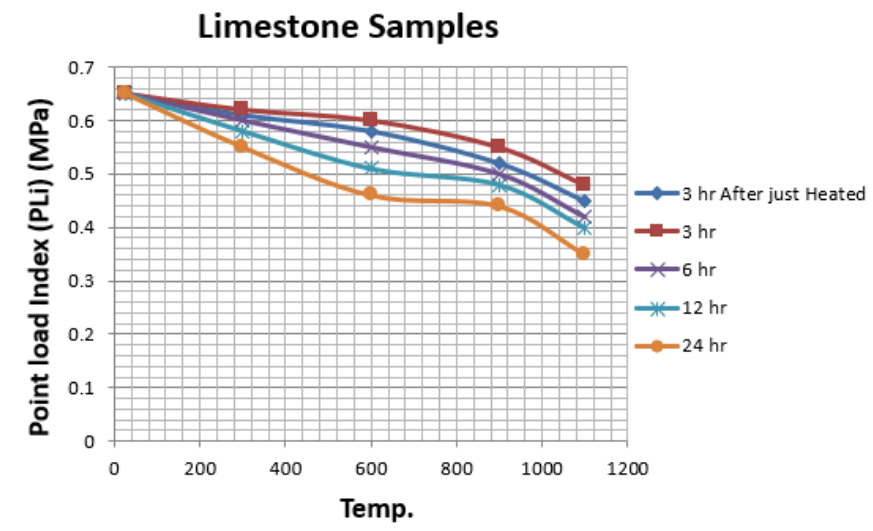

Figure 9 Variation of the (PLI) (MPa) of Limestone rock for different temperature degrees and heating periods

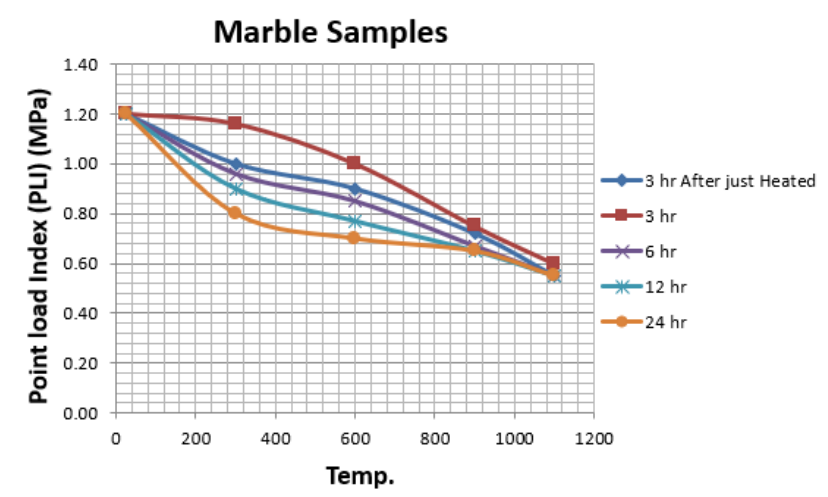

Figure 10 Variation of the (PLI) (MPa) of Marble rock for different temperature degrees and heating periods

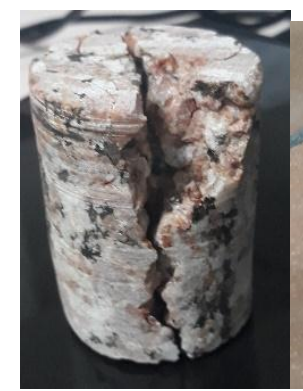

A: $300{ }^{\circ} \mathrm{C}$

Fig. 11. Mode of failure under the influence of heat after the PLI test for Granite rocks

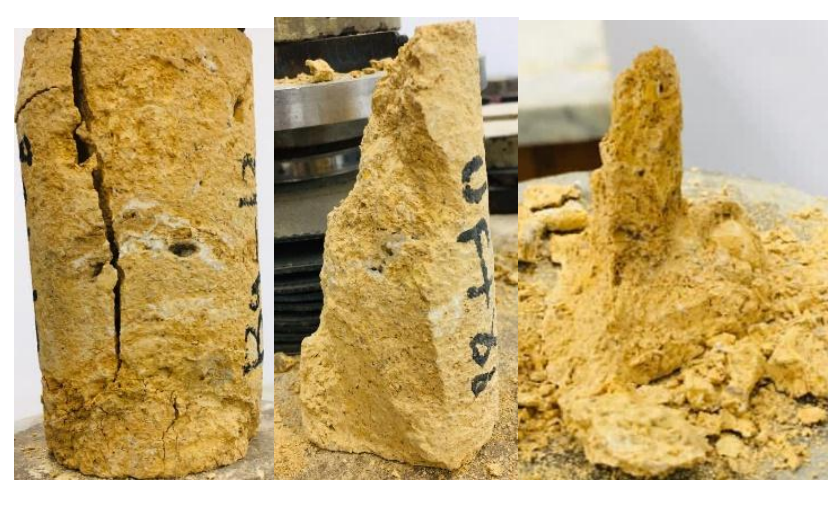
A: $300{ }^{\circ} \mathrm{C}$
B: $600{ }^{\circ} \mathrm{C}$
C: $1100^{\circ} \mathrm{C}$

Fig. 12. Mode of failure under the influence of heat after the PLI test for Sandstone rocks 


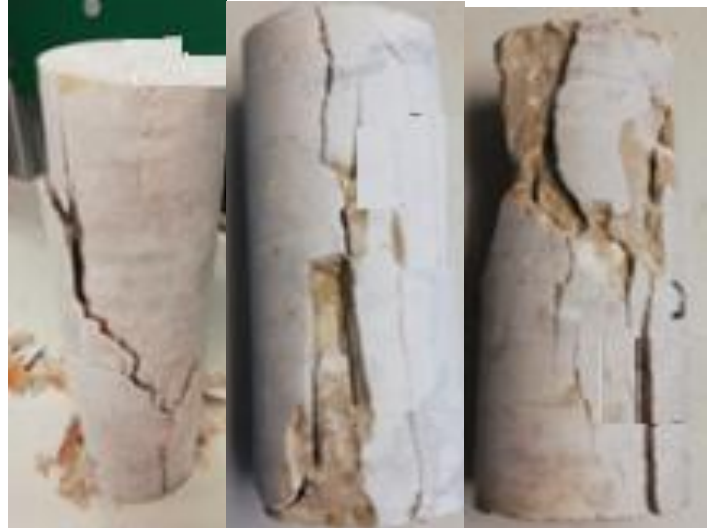
A: $300{ }^{\circ} \mathrm{C}$
B: $600{ }^{\circ} \mathrm{C}$
C: $1100{ }^{\circ} \mathrm{C}$

Fig. 13. Mode of failure under the influence of heat after the PLI test for Limestone rocks

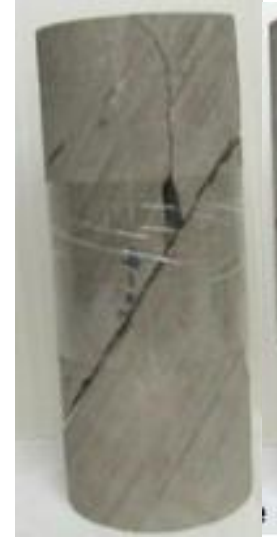

A: $300{ }^{\circ} \mathrm{C}$

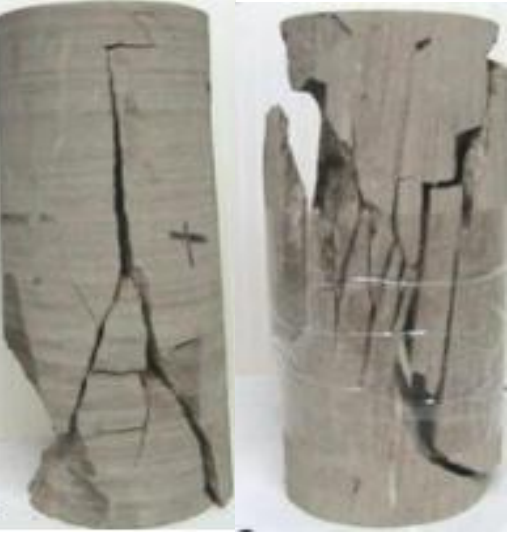

B: $600{ }^{\circ} \mathrm{C}$

C: $1100{ }^{\circ} \mathrm{C}$
Fig. 14. Mode of failure under the influence of heat after the PLI test for Marble rocks

The (PLI) (MPa) for Granite has a significant decreasing in strength upon heating up to $1100{ }^{\circ} \mathrm{C}$ by a range from $9 \%$ to $27 \%$ (compared with the initial value) for different heating periods

Sandstone rocks has a rising roughly to $\left(300{ }^{\circ} \mathrm{C}\right)$ by 115 $\%$ then decreased sharply by range from $15 \%$ to $33 \%$ (compared with the initial value) for different heating periods

For Limestone rocks a decreasing tendency from the room temperature to a certain temperature of $1100{ }^{\circ} \mathrm{C}$ by a range from $46 \%$ to $65 \%$ (compared with the initial value) for different heating periods

The (PLI) (MPa) for Marble rocks has a slight decrease up to $300{ }^{\circ} \mathrm{C}$ treatment after that a significant decrease by approximately a range from $45 \%$ to $50 \%$ (compared with the initial value) for different heating periods.

Periods of thermal effect have great influence of (PLI) (MPa) for different rocks Granite, Sandstone, Limestone and Marble from the room temperature, and up a temperature of $1100{ }^{\circ} \mathrm{C}$.

\section{CONCLUSIONS}

Based on the experimental investigations of the Point Load Index of Granite, Sandstone, Limestone and Marble rocks during and after excessive temperature treatment, the following conclusions would be drawn:
The (PLI) (MPa) for Granite has a decreasing tendency upon heating from the room temperature and up to $1100{ }^{\circ} \mathrm{C}$ by a range various between $9 \%$ and $27 \%$ (compared with the initial value) for different heating periods. Sandstone rock is increased roughly when heated up to $\left(300{ }^{\circ} \mathrm{C}\right)$ and then is decreased sharply by a range between $15 \%$ and $33 \%$ (compared with the initial value) for different heating periods.

For Limestone rocks, there is a decreasing tendency of PLI when heated various between room temperature up to $1100{ }^{\circ} \mathrm{C}$ by a range various between $46 \%$ and $65 \%$ (compared with the initial value) for different heating periods. The Marble rocks have a slight decrease up to 300 ${ }^{\circ} \mathrm{C}$ followed by a significant decrease by approximately a range of $45 \%$ and $50 \%$ (compared with the initial value) for different heating periods.

Periods of thermal effect has a great influence of (PLI) (MPa) for Granite, Sandstone, Limestone and Marble rocks from the room temperature, and up temperature of $1100{ }^{\circ} \mathrm{C}$.

\section{REFERENCES}

[1] Brotons V, Toms R, Ivorra S, Alarcn JC (2013) Temperature influence on the physical and mechanical properties of a porous rock: San Julian's calcarenite. Eng Geol 167:117-127.'

[2] Burton E, Friedmann J, Upadhye R (2007) Best practices in underground coal gasification. Lawrence Livermore NationalLaboratory, USA.

[3] Cherubini Y, Cacace M, Scheck-Wenderoth M, Moeck L, Lewerenz B (2013) Controls on the deep thermal field: implications from 3-D numerical simulations for the geothermal research site Gro Schonebeck. Environ Earth Sci 70(8):3619-3642.

[4] Dwivedi RD, Goel RK, Prasad VVR, Sinha A (2008) Thermomechanical properties of Indian and other granites. Int J Rock Mech Min Sci 45:303-315.

[5] Hajpal M, Torok A (2004) Mineralogical and color changes of quartz sandstones by heat. Environ Geol 46:311322

[6] Hokmark H, Claesson J (2005) Use of an analytical solution for calculating temperatures in repository host rock. Eng Geol

81:353-364.

[7] Gautam PK, Verma AK, Sharma P, Singh TN (2018) Evolution of thermal damage threshold of Jalore granite. Rock Mech Rock Eng 51(9):2949-2956

[8] Gautam PK, Verma AK, Sharma P, Singh TN (2018) Evolution of thermal damage threshold of Jalore granite. Rock Mech Rock Eng 51(9):2949-2956.

[9] Gelet R, Loret B, Khalili N (2012) a thermo-hydromechanical coupled model in local thermal non-equilibrium for fractured HDR reservoir with double porosity. J Geophys Res 117: B07205.

[10] Gibb FGF, Travis KP, McTaggart NA, Burley D (2008) A model for heat flow in deep borehole disposals of highlevel nuclear waste. J Geophys Res 113:BO5201. DOI: 10.1029/2007JB005081

[11] Nakaten N, Schlu“ ter R, Azzam R, Kempka T (2014) Development of a techno-economic model for dynamic calculation of the cost of electricity, energy demand, and 
$\mathrm{CO} 2$ emissions of an integrated UCG-CCS process. Energy 66:779-790

[12] Ringwood AE (1985) Disposal of high-level nuclear wastes-a geological perspective. Mineral Mag 49(351):159-175

[13] Qing-bin Meng, Wei Qian. Jiang-feng Liu, Ming-wei Zhang, Meng-meng Lu, and $\mathrm{Yu} \mathrm{Wu} \mathrm{(2020)} \mathrm{Analysis} \mathrm{of}$ triaxial compression deformation and strength characteristics of limestone after high temperature. https://doi.org/10.1007/s12517-020-5151-0

[14] Sanchez M, Gens A, Guimaraes L (2012) Thermalhydraulic mechanical (THM) behavior of a large-scale in situ heating experiment during cooling and dismantling. Can Geotech J 49(10):1169-1195.

[15] Shao, S.; Ranjith, P. G.; Wasantha, P. L. P. et al. (2015) Experimental and numerical studies on the mechanical behavior of Australian Strathbogie granite at high temperatures: An application to geothermal energy. // Geothermics. 54, 54, pp. 96-108.

[16] Tian H, Kempka T, Xu NX, Ziegler M (2013) A modified Mohr-Coulomb failure criterion for intact granites exposed to high temperatures. Springer Series in Geomechanics and Geoengineering, Berlin, pp 379-393

[17] Tian H, Ziegler M, Kempka T (2014) Physical and mechanical behavior of claystone exposed to temperatures up to 1000 C. Int J Rock Mech Min Sci 70:144-153.

[18] Yang, S. Q.; Ranjith, P. G.; Jing, H. W. et al. (2017) An experimental investigation on thermal damage and failure mechanical behavior of granite after exposure to different high-temperature treatments. // Geothermics. 265, pp. 180197.

[19] Yan Qin, Hong Tian, Neng-Xiong Xu, and Yu Chen (2020) Physical and Mechanical Properties of Granite after High-Temperature Treatment. //Rock Mechanics and Rock Engineering, 53:305-322.

[20] Younger PL (2011) Hydrogeological and geomechanical aspects of underground coal gasification and direct coupling to carbon capture and storage. Mine Water Environ 30(2):127-140. 